\title{
Lacunarity, lexicography and beyond: integration of the introduction of a linguo-cultural concept and the development of L2 learners' dictionary skills
}

\author{
Joanna Szerszunowicz ${ }^{1}$ (D)
}

Received: 14 March 2015/ Accepted: 9 June 2015/Published online: 28 July 2015

(C) The Author(s) 2015. This article is published with open access at Springerlink.com

\begin{abstract}
The paper discusses the integration of presenting theoretical linguocultural knowledge and developing dictionary skills in advanced students of a foreign language. The proposed approach allows showing students the interdisciplinary character of various issues, one of which is cross-linguistic lacunarity. It is given as an example of a phenomenon, whose introduction can be combined with the development of students' dictionary use abilities. Lacunarity consists in the lack of some source language elements in the target language. Two main kinds of lacunae are distinguished: linguistic and referential ones. The focal issue of the paper is how the information on the lacunary character of words can be presented to advanced students of English as a foreign language, in this paper Polish learners, so that they could consider the phenomenon in terms of bilingual lexicography: first, becoming aware of the specifics of their description; second, practising their dictionary skills by analysing entries for selected lacunary lexical and phraseological units; third, combining the information and skills in doing creative tasks, related to lacunarity and its bilingual lexicographic descriptions. Furthermore, additional activities are proposed for revising the acquired knowledge on lacunarity and advancing dictionary use. Offering students tasks, which require them to adopt a different perspective, aims to increase their involvement in the learning process and to foster their autonomy as learners. Encouraging learners to reflect on lacunae and their lexicographic description is expected to familiarize them with the phenomenon and simultaneously to develop their dictionary skills by doing especially designed activities.
\end{abstract}

Keywords Lacunarity - Zero equivalent · Dictionary reference skills · Bilingual lexicography

Joanna Szerszunowicz

joannaszersz@gmail.com

1 The University of Bialystok, Białystok, Poland 


\section{Significance of integrating the concept of lacunarity and dictionary skills}

The inclusion of cultural aspects in foreign language teaching is widely acceptedas emphasized by Kramsch (2000: 3), a given language expresses, embodies and symbolizes cultural reality. It functions in a concrete reality, in which there are particular phenomena, named by the language, which is not only a carrier of meanings, but also expresses evaluations and widespread beliefs. It is its cumulative function that makes it possible for learners to trace cultural influences by analysing lexis, phraseology, grammar, etc. Therefore, the introduction of linguo-cultural phenomena is important for enhancing students' linguistic knowledge and developing their awareness. One of the notions worth presenting is cross-linguistic lacunarity, which can be briefly defined as the existence of gaps between two languages: the learners' mother tongue (L1) and the foreign language which they learn (L2).

Since lacunarity consists in the lack of interlingual equivalents of given language elements, it is a phenomenon not only worth researching in a theoretical perspective, but also in a practical one, especially from the point of view of foreign language teaching (Turunen 2006), translation studies (Panasiuk 2005) and bilingual lexicography (Szerszunowicz 2013). As for the first area, the notion is important for many reasons. Generally speaking, learning a foreign language means students' adopting a new cognitive perspective and their functioning in a new cultural reality, which is different in many respects from the ones of their own. Therefore, the L2 learner is exposed to various kinds of gaps during the learning process.

For instance, students easily notice lacunae while studying vocabulary. The zero equivalence of such words results from the fact that certain L1 words do not have corresponding lexical units in L2. Many of such items are culture related, naming realia of learners' own culture $(\mathrm{C} 1)$ or of the ethnic community, whose language they learn (C2). Lacunarity is by no means limited to lexis: students also observe certain lacunary sounds or grammatical phenomena of L2. Then, at a higher level of language education, students encounter more complex kinds of gaps, like lacunae in a variety of genres of the two ethnic communities.

From a bilingual lexicographic perspective, zero-equivalent units also form an important group of lexical items. Due to the lack of a cross-linguistic equivalent, the lexicographer has to decide on the best solution to be used for a given entry. Language gaps have to be filled in a way allowing a foreign language learner to acquire a unit which is linguistically and often also culturally new to him/her. Providing a translation equivalent, giving an explanatory definition and/or including a visual image are frequently used to deal with gaps in bilingual lexicographic description.

Lexicographic works are thus important sources of information, facilitating students' acquiring lexical lacunae. Dictionaries are often the learner's only sources of information on such gaps. Therefore, it seems to be advisable to teach L2 students the linguo-cultural knowledge to understand lacunary units from a cross-linguistic 
perspective and to make them understand how useful dictionaries are in dealing with lacunae.

The aim of the paper is to present the way in which the concept of lacunarity can be integrated with the development of dictionary skills in advanced EFL students. The specific objectives are twofold: first, to illustrate how the introduction of the notion of lacunarity enriches students' theoretical basis, which consequently enhances their general linguistic knowledge and fosters language awareness; second, to discuss how the introduction of the phenomenon can create an opportunity for students to implement the new knowledge while practising dictionary reference skills, which contributes to the development of their learning autonomy.

\section{Lacunarity: an overview}

The comparison of two languages, or, in a broader perspective, two cultures, allows for determining both similarities and differences. The latter are most discernible in the case of cross-linguistic gaps, created by L1 units with zero equivalents in L2 units and vice versa. It is worth adding that such empty places can exist in all subsystems of given languages. They are called lacunae; the term stems from the Latin word lacuna meaning 'gap' or 'lake'. As explained by Anokhina (2013: 168), "the lacuna-etymon is of Greek origin $\lambda \alpha \kappa(<\lambda \alpha \kappa \kappa \omega \mu \alpha)$, but later the word was mostly referred to as of the Latin origin (...)". The branch of science which studies lacunae of language, speech and cognition is called lacunology.

Although the existence of lacunae in a cross-linguistic perspective is a commonly known phenomenon, systematic studies on gaps started in the nineteenth century and gained impetus only after the development of ethno-psycholinguistics in the 1970s and 1980s (Schröder 2006: 74). The notion of lacunae was first suggested with reference to the gaps in a text, represented by non-equivalent lexical units and other culture-bound items, in the French-Canadian School (Vinay and Darbelnet 1958); then it was developed in Russia by Sorokin, Markovina and other scholars (Anokhina 2013: 166).

It is noteworthy that an American linguist, Kenneth L. Hale, proposed independently a similar concept in the 1970s. Discussing grammar and culture of native Australians, "Hale described the absence of numerals and colours designations in the language and culture of the Australian aboriginals as gaps" (Schröder 2006: 74). At the beginning, the term lacuna was used in translation studies and stylistics (Vinay and Darbelnet 1958). However, nowadays lacunarity is a notion which is useful in various areas of research.

Since lacunarity is a complex phenomenon, which can be analysed from various perspectives, the Lacuna Theory has several models (e.g. Ertelt-Vieth 2006: 52; Anokhina 2013: 171). Table 1 represents one, based on Anokhina (ibid.).

Even this brief presentation shows the interdisciplinary character of research on lacunarity. Nowadays, scholars from various disciplines research lacunae: for instance, ethnopsychology (Sorokin and Markovina 2010), advertising research (Grodzki 2003), translation studies (Pym 1993; Panasiuk 2005), film studies (Sard 
Table 1 Typology of lacunae

\begin{tabular}{ll}
\hline Kind of lacunae & Cluster of lacunae of a given kind \\
\hline Lacunae in language & Linguistic gaps (phonetic, lexical, grammatical, etc.) \\
Lacunae of cognition & Lacunae of experience, linguistic thesaurus, background knowledge \\
Lacunae of time & Diachronic and synchronic lacunae \\
Lacunae in speech & Pauses (psychological, hesitative, apprehension) \\
Vague element of culture & National specifics (realities, proper names, onomasticon) \\
\hline
\end{tabular}

2006), foreign language teaching (Turunen 2006) and linguistics (Lehrer 1970, 1974; Wipprecht 2005; Bykova 2006; Anokhina 2013). ${ }^{1}$

In terms of contrastive linguistic research, as already mentioned, lacunae can be analysed at various levels of language: phonological, morphological, lexical, phraseological, syntactic, textual, etc. (Bykova 2006: 139). As for lexical lacunae, briefly speaking, a gap occurs when a concept expressed in one language by means of a word is not expressed by a corresponding lexical unit in another language (cf. Lehrer 1970, 1974; Wipprecht 2005). Lacunary units constitute a group of items, whose properties differ in a contrastive perspective.

According to Dagut (1981), one can distinguish linguistic gaps and referential ones. A linguistic gap is created by an L2 word, which expresses a given meaning in L2 and does not have a corresponding lexical items in L1, but whose meaning is comprehensible to L1 users. It holds for L1 words which have no equivalents in the form of words in L2. For example, if English and Polish are compared, the word drawl constitutes a cross-linguistic lacuna. In a bilingual English-Polish dictionary, three meanings of this lexical unit are explained in a descriptive way:

\section{drawl $^{2}$}

1. przeciąganie samogłosek [drawling]

2. powiedzieć (coś) przeciągając samogłoski [to say (sth) drawling]

3. mówić przeciągając samogłoski [to speak drawling] ${ }^{3}$ (WSAP).

This word belongs to linguistic gaps, since there is no Polish single-word equivalent, but all the senses are comprehensible to native users of Polish.

The other kind is a referential lacuna, which arises when an L2 word is a carrier of a meaning not known to learners of this language, or when an L1 word expresses a sense not known to L2 native speakers. It results from the fact that the lexical item refers to the foreign culture notions, which are unknown to students, but can be described and still not fully comprehensible to them. In the English-Polish

\footnotetext{
${ }^{1}$ A comprehensive bibliography on various works on lacunarity is included in Panasiuk and Schröder, eds. (2006: 328-347).

2 The pronunciation and grammatical information are omitted, as they are not relevant to the discussed issues.

3 All translations of the entries in square brackets are provided by the author of the paper.
} 
perspective, an example is the trade name Marmite $^{\circledR}$, defined as 'ekstrakt z drożdży i warzyw' [yeast and vegetables extract] (WSAP). ${ }^{4}$ The label $G B$ gives the information that the unit is used in British English. On reading such an explanation, the Polish learner is able to have a very general understanding of the word Marmite $^{\circledR}$ and to know which variety of English it belongs to, but, in fact, the unit creates a sense of gap, since the product is not known in the Polish culture.

Undeniably, both kinds of lacunary words are problematic from the point of view of teaching and learning foreign languages. In the case of linguistic gaps, their lacunary character results from a different verbalization of a given sense in two languages: i.e. conceptualizations of particular notions vary. Moreover, stylistic properties may differ significantly, which is exemplified by humorous or depreciative nicknames of inhabitants of different regions; marked L2 units often may have only neutral descriptive L1 equivalents and vice versa. However, it can be assumed that referential gaps, exponents of national specifics (Sternin 2004: 21), are felt to be more difficult by learners who have to deal with L2 names of phenomena, objects, etc., which do not exist in their own cultural reality.

\section{Integration of linguo-cultural knowledge and dictionary skills}

\subsection{Theoretical aspects}

In the process of learning a foreign language, dictionaries constitute a very important source of information. In fact, L2 students start using dictionaries very early: bilingual lexicographic works are used by primary-school students, who learn about this kind of reference books and need to be instructed on how to use them (Lew and Galas 2008). In fact, using a dictionary is a skill which needs to be learnt and further developed over the whole period of L2 learning. Therefore, proper dictionary education and skills training is important for proper L2 learning and has been stressed by many scholars (e.g. Béjont 1989; Tono 2001; Yamada 2001, 2014).

Taking into consideration their learning experience, it can be assumed that advanced students have a good command of English and sufficient dictionary skills. Moreover, they should be familiar with the dictionary typology, ${ }^{5}$ which means that it can be expected that they use various lexicographic works, both paper and electronic. ${ }^{6}$ They should also have adequate intercultural competence and display sensitivity to cultural differences reflected in languages, different viewpoints, and various conceptualizations of phenomena in L1 and L2 (Szerszunowicz 2011). It is of importance, since the dictionary is a source not only of linguistic information, but also of cultural knowledge.

\footnotetext{
${ }^{4}$ Selected trade names are included, since they are used in a generic sense. Simultaneously, such names can function both as proper names and as appellatives. Moreover, they are included in the consulted bilingual lexicographic works (e.g. WSAP, WSPA).

5 The typology of lexicographic works has been attempted by a number of scholars (Hartmann 2001).

${ }^{6}$ On the use of paper and electronic dictionaries, see Dziemianko (2012). The challenges of the shift from print to electronic dictionaries are analysed by Yamada (2011).
} 
Therefore, it is the complex character of lexicographic description ${ }^{7}$ that leaves room for further development of advanced students' dictionary skills. It can be assumed that they can still be assisted by the teacher, so that they can be more efficient in searching for the information which they need. When they have necessary knowledge and skills, new possibilities of their lexicographic education arise, one of which is the interdisciplinary approach, allowing for combining various aspects of knowledge and skills.

As already mentioned, it can be assumed that advanced students are familiar with basic linguistic notions which were presented in their mother tongue classes as well as English lessons. Thanks to this education, they are able to decode the information regarding grammar (e.g. parts of speech or gender) as well as stylistic value (labels) and collocability. Moreover, one can expect them to interpret not only purely linguistic characteristics of the searched words or phrases, but also the elements of cultural knowledge related to the lexical items. Discussing such items from a lexicographic point of view favours the introduction of the notion of lacunarity, which might be a good opportunity for expanding students' linguo-cultural knowledge while using dictionaries.

Cultural information is well present in many dictionaries, including the bilingual ones. The place of cultural knowledge in a bilingual dictionary is discussed by Rodger, who emphasizes that "the general-purpose bilingual dictionary can also serve as a bridge between cultures, or (as cultures are not monolithic) between two sets of cultural understandings" (Rodger 2006: 572). It should be noted, in this connection, that the inclusion of glosses and culture boxes results in the hybrid character of a bilingual dictionary (Szerszunowicz 2011, 2012).

Therefore, in a broader perspective, the term linguo-cultural could be preferred over linguistic, since using the former allows for the inclusion of notions from not only linguistics proper, but also from ethnolinguistics. Taking into consideration the fact that developing intercultural skills is part of the language acquisition process, the inclusion of elements of linguo-cultural theoretical information is beneficial for dictionary users. It fosters students' autonomy, since they feel more independent in using lexicographic works. In the case of the awareness of the existence of lacunary lexical items, the knowledge is likely to increase the users' attention to such words and their special cross-linguistic status.

\subsection{Towards practice: lacunarity and dictionary skills}

As lacunarity is a phenomenon, which is very important for non-native speakers of a given language, it can be assumed that it is worth including this element of theoretical knowledge into the English teaching process. Advanced students are

\footnotetext{
7 Nowadays, to a great extent due to technological development, dictionaries undergo evolution and students' dictionary skills need to be constantly developed, so that they could take advantage of what contemporary lexicography offers. As Yamada (2010: 159) stresses, writing about the need to teach dictionary skills: "Yet, in the age of electronic dictionaries, it has become difficult to keep abreast of the current dictionaries and their increasingly sophisticated function". A discussion on the evolution of users' dictionary skills conditioned by changing from paper to electronic dictionaries is presented in Lew (2013). See also Lew and de Schryver (2014), Ronald and Ozawa (2011).
} 
bound to have encountered many lacunary phenomena while learning, yet providing them with some information on cross-linguistic gaps will facilitate their understanding of lack of correspondences between two languages and the implications of zero equivalence for interlingual communication.

The question arises how the notion should be presented. A proper introduction of lacunarity should perform three functions: first, it has to familiarize students with the phenomenon of gaps in a cross-linguistic perspective; second, its role is to interest and involve students in problem solving; third, it ought to be a good starting point for dictionary skill activities. In fact, the presentation of lacunarity can be done in many ways, some of which are proposed below:

1. Students can be asked to read a text on lacunae provided by the teacher at home. The text is used as a warm-up at the beginning of the next lesson, for instance, and a set of comprehension questions is asked, followed by a discussion.

2. Students are divided into groups. Each group is given a paragraph on the phenomenon of lacunarity (e.g. Group 1: historical outline of lacunarity; Group 2: spheres of occurrence of lacunarity; Group 3: lacunarity in language; Group 4: division of lacunary lexical items; Group 5: lacunarity in communication; etc.). Students read the texts in groups and then present a summary to other groups.

3. Students read a text on lacunarity and do the text-related activities prepared by the teacher (multiple-choice questions, true/false, matching titles).

4. The information on lacunarity can be given by a student in his/her individual presentation or by teams assigned lacunarity-related subjects. Alternatively, the teacher can deliver a mini-lecture, preferably with accompanying activity sheets.

It is the teacher's decision how to introduce the notion of lacunarity to students. Factors like the following should be considered: the specific character of the group and students' preferences of learning styles, their abilities, the skills which are to be practised simultaneously, etc. Irrespective of the introduction, the students should have a clear idea of what lacunary gaps are and why they are so important in a crosslinguistic perspective.

The next step is to combine the acquired elements of theoretical linguistic knowledge with dictionary use. Students' attention should be drawn to the fact that the lack of equivalents causes problems in many areas, such as translation and bilingual lexicography. This question should be posed to the students: In what areas of human activity do the problems of cross-linguistic lacunarity occur? If they have difficulty in answering the question, they should be given a list of possible areas (e.g. translation, bilingual lexicography, everyday communication, foreign language learning). Then the students should be asked to think about potential problems in each area.

In the context of discussing lacunarity, using a bilingual dictionary has one more advantage: it makes it easier to detect lacunae. Adamska-Sałaciak (2010) draws attention to the significant role of bilingual dictionaries in many situations the 
learner of L2 encounters, in which the use of a bilingual dictionary is preferred over that of a monolingual one. ${ }^{8}$

The first step to show gaps to students is an analysis of a few dictionary entries, containing an explanation of a word, which does not exist in the target language. Students can be asked to find the L1 equivalents of L2 words and vice versa, constituting linguistic and referential lacunae; for instance, in the Polish-English perspective, ${ }^{9}$ such words as churchgoer/haggis ${ }^{10}$ and bezterminowo/kierpec. Students use bilingual dictionaries, printed and/or electronic, to look up the words and compare their findings in groups, focussing on the lexicographic description of the selected words.

If they consult WSAP and WSPA, they find the following information:

churchgoer Relig osoba $f$ regularnie chodząca do kościoła, człowiek m religijny or praktykujący [a person who regularly goes to church, a religious person or a practising person] (WSAP),

bezterminowo for an indefinite period (WSPA), kierpec $m$ zw. pl a shoe traditionally worn by Polish highlanders (WSPA).

A very preliminary analysis shows that words do not have corresponding lexical units are provided with explanatory equivalents (Zgusta 1984). It can also be seen that meanings of referential gaps are given in italics in WSPA.

Then, students can be given several examples of bilingual entries for lacunary units, like the ones below:

Blue-tack $^{\circledR}$ Blu-tack (substancja do przyklejania plakatów itp. do ścian) [Blutack (substance for sticking posters, etc. to walls)] (WSAP),

Bombay mix Culin potrawa indyjska z soczewicy i orzeszków ziemnych [Indian dish from lentils and peanuts] (WSAP),

custard pie Culin $\approx$ markiza [markiza is a name of a Polish product resembling the custard pie] (WSAP),

jam session Mus infml jam session [jam session] (WSAP),

jetlag zmęczenie po długiej podróży samolotem (spowodowane zmianą stref czasowych) [tiredness after a long journey (caused by a change of time zones)] (WSAP),

jelly baby żelek ( $w$ ksztatcie dziecka) [jelly (in the shape of a baby)] (WSAP), jelly bean żelek (w kształcie fasolki) [jelly (in the shape of a bean)] (WSAP),

\footnotetext{
8 Adamska-Sałaciak (2010: 123) presents the arguments in favour of bilingual dictionaries in two broad categories: "those related to the profile of the intended user and those following from the method of conveying meaning associated with a particular dictionary type". She emphasizes that bilingual lexicographic works are more user-oriented and are particularly useful for culture-specific vocabulary in the case where L1-L2 contrasts are highlighted. A bilingual dictionary offers L2 equivalents which are useful for names of fauna and flora kinds, serving to avoid certain problems related to defining (idem per idem, obscurum per obscurius, elusive hyperonyms). On bilingual learners' dictionaries, and see also Tomaszczyk (1983), and Lew and Adamska-Sałaciak (2015).

9 English-Polish and Polish-English dictionaries are discussed by Piotrowski (2001: 176-219).

10 The entries on haggis are presented on page 10 .
} 
jelly mould GB, jelly mould US salaterka/forma na galaretkę [jelly bowl/form] (WSAP).

Their task consists in analysing how the gaps have been dealt with in the selected lexicographic works. They should identify the following kinds of equivalents: a borrowing, a borrowing and an explanation, a translational equivalent, an explanatory definition, a substitution with a hyperonym followed by additional information, and a functional equivalent. The compounds with the constituent jelly are interesting examples of cross-linguistic gaps: in fact, jelly sweets are known in Poland; however, they usually are formed in different shapes: teddy bears, raspberries, snakes, and geometrical shapes (e.g. cubes). Therefore, the information regarding the shape has to be added. There is no special term commonly used for a jelly mould, so no corresponding phrase exists in Polish; that is why a translational equivalent was used.

The second task consists in students' giving a critical evaluation of the findings of lexicographic search. They can be given several questions to help them, for instance: How do you evaluate the descriptions of the words? Which gaps are more difficult to explain for lexicographers? How can shortcomings of lexicographic descriptions be overcome? It can be expected that students will concentrate on referential gaps and suggest that the entries should be more informative. They might request the provisions of the pictures of kierpec or haggis. After the completion of the task, they should be aware of the fact that there are levels of difficulty for lexicographic description of lacunary words in bilingual dictionaries.

Further activities may deal with more complex problems, like the asymmetry of equivalence of meanings of polysemous words. For example, if the word clambake is analysed in an English-Polish perspective (WSAP), it can be concluded that the Polish language does not have a single-word meaning 'a picnic on the beach when one eats seafood', so a linguistic lacuna is observed. However, the second meaning of the word clambake, 'a noisy party', has a word equivalent hulanka. This phenomenon can be illustrated by other examples such as:

\section{bigos}

1. Kulin. stewed dish made of sauerkraut and/or fresh cabbage, meat and mushrooms,

2. mess, narobić $\sim \mathrm{u}$ to mess things up, to make a mess of things (WSPA),

\section{doba}

1. (24 godziny) $24 \mathrm{~h}$, day (and night),

2. przen. (epoka) age, era,

3. Geol. era (WSAP). 
The latter includes a culture-specific meaning and a metaphorical one, which does not constitute a lacuna in a cross-linguistic perspective.

Moreover, other kinds of lacuna may be analysed, including the stylistic ones. The above-quoted bilingual dictionary includes offensive names of nationalities such as:

Chicano obywatel, -ka Stanów Zjednoczonych pochodzenia meksykańskiego [a US citizen of Mexican origin] (WSAP),

Paddy infml offensive Irlandczyk [Irishman] (WSAP),

Paki GB vinfml offensive Pakistańczyk, Pakistanka, pakistański [Pakistani] (WSAP).

Students can be asked to analyse such nationality names and consider whether they are real equivalents. According to the dictionary, there are no offensive names for US citizens of Mexican origin and Irish or Pakistani people in Polish. Therefore, the correspondence can be summarized in the following way: a stylistically marked English name versus a neutral single-word Polish name. In this case, students' attention should be drawn to the role of labels as indicators of usage.

Students can also be asked to compare how the above words are presented in various dictionaries. If $\mathrm{BAB}$, an online dictionary, is consulted, the search for Paki yields the result ciapaty, which is an umbrella word referring to a Pakistani, Hindu or any other dark-skinned person. However, it is not commonly used and not known to the vast majority of speakers of Polish. Paddy is described in the same way as in WSAP, while Chicano is not included in BAB. Such activities show students that they should consult multiple sources to determine a lacuna. The conclusion is that although the dictionary contains equivalents, some English items can be classified as stylistic lacunae in Polish. The activities can be devised to address other aspects, such as collocability, pragmatic value, evaluative load, etc.

Another possibility for students is to expand on the information which the bilingual dictionary entry contains. The meaning of a lacunary unit is often given in the form of an explanatory definition, which offers the most relevant elements of cognitive knowledge on the notion. While learning about lacunarity, students should develop the ability to critically evaluate explanations in bilingual dictionaries and to search for further information.

Students can be asked to collect at least three explanatory definitions of a given referential gap from the bilingual dictionaries suggested by the teacher. The definitions will be used during the lesson. Four explanatory definitions of haggis from four English-Polish dictionaries are given below:

\section{haggis}

Scot Culin potrawa z podróbek baranich [a dish made from sheep offal] (WSAP), szkocka potrawa narodowa z podróbek baranich [a Scottish national dish made from sheep offal] (STAN),

U Scot. Kulin. przypominająca kaszankę potrawa z podrobów baranich, łoju i owsa [a dish resembling blood pudding, made from sheep offal, suet and oats] $(\mathrm{NK})$, 
potrawa z podróbek baranich [a dish made from sheep offal] (BAB).

Discussing the differences is the first stage of making an extended entry. Students may observe that STAN mentions that it is a Scottish national dish, while NK contains more detailed information on the ingredients and makes a reference to a Polish dish resembling haggis called kaszanka. The learners can evaluate the entries, analysing their contents, choosing the most adequate and justifying their choices.

Then, the students are asked which kinds of lexicographic works they would refer to know more about culture-specific names, for example, haggis and custard. The students can share their previous experiences in group discussions, which will lead to an open discussion moderated by the teacher who advises on additional available resources.

Next, the students are given the two excerpts containing additional information on haggis:

1. Haggis $[\mathrm{C}, \mathrm{U}]$ a famous Scottish dish made mainly from a sheep's or calf's heart, lungs and liver and boiled in a bag made from part of a sheep's stomach. Haggis is traditionally eaten by the Scots on Burns Night (OGBAC),

2. Haggis, nowadays the classic Scottish dish, consumed on Burns Night with its traditional accompaniment of bashed neeps (mashed swedes) or clapshot and whisky, was in fact widespread south of the Border up until the early eighteenth century. By 1771 Tobias Smollett could write, in Humprey Clinker, 'I am not yet Scotchman enough to relish their singed sheep's-head and haggice', but against this dialect glossaries show that something called haggis was still eaten in country areas of England, such as Gloucestershire and Shropshire, in the nineteenth century.

The quintessential Scottish haggis, apostrophized by Burns as 'great chiftain o' the pudding'-race', consists typically of sheep's heart, liver, and lungs, cooked and then chopped up with onions, oatmeal, and seasonings and stuffed sausagelike into a sheep's stomach. The origin of its name (which is first recorded in the early fifteenth century) is something of an enigma (...). (AZ).

The students are asked to analyse them, working in pairs, and to choose the information which is relevant from the bilingual lexicographic perspective. They have to focus on what is important from a cognitive point of view in a crosslinguistic perspective. Then, they have to include the selected information in an explanatory definition of the name haggis.

The next stage is the discussion of the explanations produced by the students. An example of such a definition is given below:

potrawa $\mathrm{z}$ podróbek baranich przypominająca kaszankę, tradycyjna potrawa szkocka spożywana podczas Nocy Burnsa [a dish made from sheep offal resembling blood sausage, traditional Scottish dish eaten on Burns Night]. ${ }^{11}$

\footnotetext{
11 The definition was proposed by one of the students attending a seminar held by the author at the University of Bialystok in 2014.
} 
This task helps students understand the specific role of explanatory definitions for lacunary units. Such definitions provide the most important information and are very useful, but explanations given on referential gaps should be treated as a starting point for learning more on a given notion. Moreover, students of foreign languages can learn how to define the culturally relevant terms, for example, by paraphrasing the meaning and making references to one's own culture.

The discussion of the explanatory definitions of haggis creates a good opportunity of analysing the role of visual images in the description of lacunary phenomena. Although WSAP does not pictorially illustrate haggis, ${ }^{12}$ pictures can serve very well to describe lacunary units in bilingual dictionaries, especially those of referential character, for instance, culture-specific artifacts, animals indigenous to $\mathrm{C} 2$, etc.

To evaluate the usefulness of the inclusion of pictorial images, students can be asked to check in bilingual dictionaries the following Australian animals and things, for example: echidna, wallaby, wombat, pie floater, Anzac Bisucuit, Vegemite. For Polish learners, all these words constitute gaps. Then, the students can search for these units in ACD which contains visual materials, either photos or short films. They can go on to discuss the usefulness of illustrations in explaining meanings of the words from the two categories above. As a follow-up activity, they can discuss what other categories of lacunary units should be accompanied by visual images and why such presentations may be helpful for L2 learners.

\subsection{One step further: lacunarity and lexicographic hybridity}

As the above exercises show, familiarizing advanced students of English with the notion of lacunarity allows them to look at the language from a different perspective, i.e. through the notion of zero equivalence. Such an approach enables them to focus on the units and phrases which are unique to L1 or L2, at least in the contrastive perspective of these two languages.

Due to their specific character, lacunary items are important for L2 learners and additional tasks can be proposed, so that they could have more language practice, develop their dictionary skills, and consequently increase their autonomy. It can be achieved by students' individual work on lacunarity-related issues. They can be asked to select one semantic field, for instance AGE (which can be subdivided into subfields, such as, CHILDHOOD, YOUTH, MARTURITY, and OLD AGE) and collect lacunary words.

In fact, it is also possible to include multiword units and idiomatic expressions from a given field. For instance, lacunary units from the AGE field applicable to the English-Polish perspective comprise the following ones: puppy fat, mouse-potato child, gymslip mum, sweet sixteen, silver surfers, sugar daddy, grey nomad, greys on

\footnotetext{
12 There are different arguments against (e.g. a picture is not a good representation of heterogeneous categories, whose members vary greatly in parameters, pictures do not show all the distinctive characteristics, etc.) and for (e.g. a pictorial presentation facilitates memorising, visual presentations are attractive for dictionary users, etc.) the inclusion of visual materials. An analysis of selected examples of using illustrations for explaining meanings in lexicographic works is presented in Szczepaniak (2000: 173-177).
} 
trays, Methuselah mum, a Darby and Joan, sunset industry, grey power, grey pound, grey list. These units do not have either single-word equivalents or idiomatic counterparts in Polish, so explanatory definitions are provided. ${ }^{13}$

After completing this task, students present their findings and discuss them. They can make modifications on the basis of the discussion. The revised versions are copied into one file, which is sent to all students for self-study. The teacher can produce some activities using this file to consolidate the students' learning and to give quizzes on the newly acquired language items.

If multiword expressions are analysed, lacunary schemata can also be included in such activities: certain expressions are created according to a particular model, which does not exist in L1. For instance, the one JOE/JOHN/JANE + SURNAME has no Polish equivalent in terms of a model. Students can be given a list of units which are realizations of a given pattern (in this case, for instance, Joe Blow/Bloggs, John Doe, Jane Doe, Joe Citizen, Joe Lunchbox, Joe Six-Chip, John Q., John Q. Consumer, John Q. Local, Johny Jockstrap, Jane Six-Chip), so that they could check how such items are described in bilingual lexicographic works.

Another proposal is to focus on referential gaps. Since such lacunae are particularly problematic, and the analysis of referential gaps, involving various categories of information, will offer L2 learners an insight into C2. They need to find L2 words, which are semantically isolated in a cross-linguistic perspective. They can study words related to food, sports, and architecture typical of $\mathrm{C} 1$ and $\mathrm{C} 2$, respectively.

Students are divided into groups according to the subjects they deal with. For instance, if they choose food terms, their list may look like the one below: several examples of units which are lacunary in the English-Polish perspective and vice versa:

custard GB (creamy) słodki sos z mleka i jajek z dodatkiem mąki [sweet cream from milk and eggs with flour] (WSAP),

pudding 1 GB deser, 2 (sweet dish) pudding, 3. (cooked savoury dish) potrawa $\mathrm{z}$ mięsa i warzyw, gotowana na parze, często w cieście [a dish from meat and vegetables, steamed, often enclosed in a pastry] (WSAP),

toffee apple jabłko w polewie [coated apple] (WSAP),

Yorkshire pudding GB Yorkshire pudding (podawany do pieczonej wołowiny) [Yorkshire pudding (served with roast beef)] (WSAP);

kisiel Kulin. a type of gelatine dessert (WSPA),

oscypek dial. Kulin. smoked ewe's milk cheese made in the Tatra Mountains (WSPA),

\footnotetext{
${ }^{13}$ It is worth drawing attention to recent findings in Inoue (2014), who describes newly observed phraseological units with noun forms of modal verbs (shoulds and oughts, oughts and musts, shoulds and musts). Such phrases constitute a lacunae in an English-Polish perspective. Therefore, lacunarity can be combined with the notion of phraseological innovations, which can also be viewed in a lexicographic perspective.
} 


\section{pieróg}

1. Kulin. $\sim$ ogi $\mathrm{z}$ kapustą/mięsem $[\sim \mathrm{s}$ with cabbage/meat] cabbage/meat dumplings, dumplings stuffed with meat/cabbage,

2. Kulin. (pieczony [baked]) pie (WSPA)

To do the project, each student selects two words or two multi-word lexical items from the list which represent referential lacunae in a contrastive perspective: one is the student's mother tongue unit and the other is from the foreign language they learn. Their task will be to prepare a bilingual description including linguo-cultural information. Before they start their work, the teacher explains which elements can be included in the description, especially for expansion on traditional entries (e.g. idioms, intertextuality, cultural information). Moreover, they can be presented with a model entry like the one below:

Barbour /ba:bə/nazwa firmy produkującej drogie płaszcze ze specjalnie przygotowanej bawełny, która zatrzymuje deszcz i wiatr, oraz potocznie samego produktu [a name of a company producing expensive coats from specially prepared cotton, which protects the wearer from rain and wind, colloquially the name of the product]

Nazwa Barbour kojarzona jest ze stylem życia klasy wyższej. [The name Barbour is associated with the upper-class lifestyle.]

PRZYKŁAD [Example]: Do you go hunting in your old barbour?

IDIOMY [Idioms]: Barbour brigade nazwa członków bogatej klasy wyższej, zwłaszcza tych, którzy niezależnie od pogody oddają się takim rozrywkom, jak polowanie i spacery po lesie [a name of representatives of rich upper class, expecially those who, irrespective of the weather, go hunting and walking in the forest].

\section{Wariant [Variant] green-welly brigade}

Barbour $^{\mathrm{TM}}$ _nazwa firmy produkującej drogie płaszcze $\mathrm{z}$ wodoodpornej bawełny; potocznie nazwa samego produktu. Kojarzone są ze stylem życia klasy wyższej (polowania, spędzanie czasu na łonie natury niezależnie od pogody, luksus). [name of a company producing expensive coats from waterproof cotton, colloquially the name of the coat. Associated with the upper class lifestyle (hunting, being in countryside in all weather conditions, luxury)].

(Szerszunowicz 2014: 303).

Within a given period of time, they collect information from various sources, for example, bilingual dictionaries, cultural dictionaries (e.g. OGBAC), websites, etc. Then their task is to provide a bilingual description of the unit in the form of a quasientry. The inclusion of visual materials should be strongly encouraged (e.g. cartoons and photos) as well as excerpts, in which a given word or phrase is used (e.g. famous quotations including such words). The students have to indicate the sources from which they took the materials. The teacher monitors their work and assists them if necessary. When finished, this project can be shared as posters and/or a mini 
Table 2 Knowledge and skills to be acquired by students

\begin{tabular}{ll}
\hline Lacunological & Awareness of the existence of gaps in a cross-linguistic and cross-cultural perspective \\
& Knowledge of lacunae, their kinds and specifics \\
& Ability to determine gaps in a contrastive perspective \\
& Ability to fill the gap in L2 by using various techniques \\
& Knowledge of techniques and awareness of their usefulness for filling particular gaps \\
& Practical ability to use the techniques \\
& Ability to use bilingual dictionaries to find information on gaps \\
& Lexicographic knowledge (kinds of dictionaries, their macro- and micro-structures) \\
& Ability to consciously interpret bilingual entries for lacunary units \\
& Ability to critically evaluate such entries \\
& Ability to search for information on gaps in various lexicographic works \\
& and in other sources
\end{tabular}

bilingual dictionary of selected referential gaps, according to the categories dealt with. Such a dictionary can be placed on the university Intranet, so that other students can also benefit from it.

\section{Conclusion}

Lacunarity is a phenomenon, which shows how languages differ in many aspects. The introduction of lacunarity in an English classroom environment bridges theoryoriented linguistics and practice-focused language teaching. The introduction of the concept with dictionary use contributes to students' better understanding of the existence of cross-linguistic gaps and its implications for bilingual lexicography, and the proper use of various dictionaries. The aim of the paper was to draw attention to the possibility of combining new linguistic knowledge with dictionary skills. It may appear that too much emphasis is placed on lacunarity, from the perspective of general FLT practice, in which lacunarity is of minor importance. However, such an approach brings about a real integration between knowledge and skills, which is practically beneficial for learners. Table 2 sets out the spectrum of knowledge and skills to be developed and acquired with "lacunological" and "lexicographical" at the opposite ends.

To conclude, it should be stressed that efforts have to be made to develop dictionary skills at all levels of language teaching. Such skills are so important that they should not be neglected even at an advanced level. Students with a good command of English can also benefit from lessons with dictionary components, which teach new approaches to problem solving. The proposal of introducing the concept of lacunarity is only one example. It is hoped that such lessons help students to learn new language phenomena as well as the innovation and utility of various contemporary dictionaries.

Open Access This article is distributed under the terms of the Creative Commons Attribution 4.0 International License (http://creativecommons.org/licenses/by/4.0/), which permits unrestricted use, distribution, and reproduction in any medium, provided you give appropriate credit to the original author(s) and the source, provide a link to the Creative Commons license, and indicate if changes were made. 


\section{References}

\section{Dictionaries cited and their abbreviations}

ACD: Miller, Julia. 2015. Australian Cultural Dictionary. http://www.culturaldictionary.org/. Accessed 2 May 2015.

AZ: Ayto, John. 2002. An A-Z of food and drink. Oxford: Oxford University Press.

BAB: bab.la Stownik. 2015. http://pl.bab.la/slownik/angielski-polski/paki. Accessed 5 March 2015.

NK: The New Kosciuszko Dictionary English-Polish. Nowy stownik Fundacji Kościuszkowskiej angielsko-polski. 2003. Ed. J. Fisiak. Kraków: Universitas.

OGBAC: Oxford Guide to British and American Culture. 1999. Ed. Jonathan Crowther. Oxford: Oxford University Press.

STAN: Stanisławski, Jan. 1990. Wielki stownik angielsko-polski z suplementem. The great English-Polish dictionary supplemented. edn. 12. Vol. 1. Warszawa: Wiedza Powszechna.

WSAP: Wielki stownik angielsko-polski PWN-Oxford. 2002. Ed. Jadwiga Linde-Usiekniewicz. Warszawa: Wydawnictwo Naukowe PWN.

WSPA: Wielki stownik polsko-angielski PWN-Oxford. 2004. Ed. Jadwiga Linde-Usiekniewicz. Warszawa: Wydawnictwo Naukowe PWN.

\section{Other works}

Adamska-Sałaciak, Arleta. 2010. Why we need bilingual learners' dictionaries. In English Learners' Dictionaries at the DSNA 2009, eds. Ilan J. Kernerman and Paul Bogaards. Tel Aviv: K Dictionaries, 147-168.

Anokhina, Tetiana. 2013. The linguistic lacunion: cognitive mapping in schemes and terms. Journal of Education, Culture and Society 1: 166-174.

Béjont, Henri. 1989. The teaching of dictionary use: Present state and future tasks. In Wörterbücher. Dictionaries. Dictionnaires: Ein internationales Handbuch zur Lexikographie internationales Handbuch zur Lexikographie, vol. 1, eds. Franz-Josef Hausmann, Oskar Reichmann, Herbert E. Wiegang, and Ladislav Zugusta. Berlin: Moutin de Gruyter, 208-215.

Bykova, Gulchera V. 2006. Phenomenon of lacunarity: some results of theoretical apprehension and prospects of lexicographic presentation. In Lakunen-Theorie. Ethnopsycholinguistische Aspekte der Sprach- und Kulturforschung, eds. Igor Panasiuk and Hartmut Schröder. Berlin: LIT Verlag, 135-141.

Dagut, Mechab. 1981. Semantic "voids" as a problem in the translation process. Poetics Today 2(4): $61-71$.

Dziemianko, Anna. 2012. On the use(fulness) of paper and electronic dictionaries. In Electronic dictionaries, eds. Sylviane Granger and Magali Paquot. Oxford: Oxford University Press, 319-341.

Ertelt-Vieth, Astrid. 2006. Weiterentwicklung des Lakunen-Modells und der Lakunen-Theorie: axiologische Lakunen, Dreiteilung des Models, Symbole. In Lakunen-Theorie. Ethnopsycholinguistische Aspekte der Sprach- und Kulturforschung, eds. Igor Panasiuk and Hartmut Schröder. Berlin: LIT Verlag, 49-72.

Grodzki, Erica. 2003. Using Launa theory to detect cultural differences in American and German automotive advertising. Frankfurt am Main: Peter Lang.

Hartmann, Reihard, R.K. 2001. Teaching and researching lexicography. Harlow: Person Education.

Inoue, Ai. 2014. Newly observed phraseological units with noun forms of modal verbs. Lexicography 1(2): $137-157$.

Kramsch, Claire. 2000. Language and culture. Oxford: Oxford University Press.

Lehrer, Adrienne. 1970. Notes on lexical gaps. Journal of Linguistics 6(2): 257-261.

Lehrer, Adrienne. 1974. Semantic fields and lexical structure. Amsterdam: North-Holland.

Lew, Robert. 2013. From paper to electronic dictionaries: Evolving dictionary skills. In Lexicography and dictionaries in the information age. Selected papers from 8th ASIALEX international conference, eds. Deny A. Kwary, Nur Wulan, and Lilla Musyahda. Surabaya: Airlaanga University Press, 79-84. 
Lew, Robert, and Arleta Adamska-Sałaciak. 2015. A case for bilingual learners' dictionary. ELT Journal 69(1): 47-57.

Lew, Robert, and Gilles-Maurice de Schryver. 2014. Dictionary users in the digital revolution. International Journal of Lexicography 27(4): 341-359.

Lew, Robert, and Katarzyna Galas. 2008. Can dictionary skills be taught: The effectiveness of lexicographic training for primary-school-level Polish learners of English. In Proceedings of the XII EURALEX International Congress, eds. Elisa Bernal and Jannet DeCesaris. Barcelona: University Pompeu Fabra, 1273-1285.

Panasiuk, Igor. 2005. Kulturelle Aspekte der Übersetzung. Anwendung des ethnopsycholinguistischen Lakunen-Modells auf die Analyse und Übersetzung literarischer Texte. Münster: LIT-Verlag.

Panasiuk, Igor, and Hartmut Schröder. 2006. Lakunen-Theorie. Ethnopsycholinguistische Aspekte der Sprach- und Kulturforschung. Berlin: LIT Verlag.

Piotrowski, Tadeusz. 2001. Zrozumieć leksykografie [To understand lexicography]. Warszawa: Wydawnictwo Naukowe PWN.

Pym, Anthony. 1993. Lacunae and uncertain limits in Australian culture, with suggestions on their translation into Spanish. In Australia in Barcelona, eds. Kathleen Firth and Susan Ballyn. Barcelona: Universitat de Barcelona, 27-37.

Rodger, Liam. 2006. Beyond Butterscotch. The Place of Cultural Knowledge in the Bilingual Dictionary. In Proceedings XII EURALEX International Congress. Volume 1, eds. Elisa Corino, Carla Marello, and Cristina Onesti. Alessandria: Edizioni dell'Orso, 567-573.

Ronald, James, and Shinya Ozawa. 2011. Electronic Dictionary Use: Identifying and Addressing User Difficulties. In ASIALEX2011 proceedings. Lexicography: theoretical and practical perspectives. Papers submitted to the seventh ASIALEX biennial international conference Kyoto Terrsa, Kyoto, Japan, August 22-24, 2011, eds. Kaoru Akasu and Satoru Uchida. The Asian Association for Lexicography, 436-445.

Sard, Hannah. 2006. Examples of Lacunae Tension in the American Perception of Russian Culture (Through Analysis of Art Film). In Lakunen-Theorie. Ethnopsycholinguistische Aspekte der Sprachund Kulturforschung, eds. Igor Panasiuk and Hartmut Schröder. Berlin: LIT Verlag, 267-271.

Schröder, Hartmut. 2006. "Lacunae" and the Covert Problems of Understanding Texts from Foreign Cultures. In Lakunen-Theorie. Ethnopsycholinguistische Aspekte der Sprach- und Kulturforschung, eds. Igor Panasiuk and Hartmut Schröder. Berlin: LIT Verlag, 72-84.

Sorokin, Yuriy A., and Iryne Y. Markovina. 2010. Culture and text. The introduction to lacunology. Moscow: GEOTAR-Media.

Sternin, Josif. 2004. Contrastive linguistics. The problems of theory and methodology of investigation. Voronezh: Istoki.

Szczepaniak, Renata. 2000. The role of illustrations in explaining meanings in learner's dictionaries. Zeszyty Naukowe Uniwersytetu Opolskiego Filologia Angielska 11: 169-182.

Szerszunowicz, Joanna. 2011. The cultural component in bilingual dictionaries of phraseological units. In ASIALEX2011 proceedings. Lexicography: theoretical and practical perspectives. Papers submitted to the seventh ASIALEX biennial international conference Kyoto Terrsa, Kyoto, Japan, August 22-24, 2011, eds. Kaoru Akasu and Satoru Uchida. The Asian Association for Lexicography, $628-637$.

Szerszunowicz, Joanna. 2012. English-Polish Contrastive Phraseology. In Directions in English-Polish contrastive research, eds. Agata Rozumko and Dorota Szymaniuk. Białystok: Wydawnictwo Uniwersytetu w Białymstoku, 139-162.

Szerszunowicz, Joanna. 2013. On Lacunae in Contrastive Phraseology. In Phraseologie im interlingualen und interkulturellen Kontakt. Phraseology in Interlingual and Intercultural Contact, eds. Melania Fabčič, Sabine Fiedler, and Joanna Szerszunowicz. Bielsko-Biała, Budapest, Kansas, Maribor, Praha: ZORA, 161-175.

Szerszunowicz, Joanna. 2014. Kulturem we frazeografii dwujęzycznej [The cultureme in bilingual phraseography]. In Edukacja dla przyszłości, vol. 10, ed. Jan F. Nosowicz. Białystok: Wydawnictwo Wyższej Szkoły Finansów i Zarządzania w Białymstoku, 295-306.

Tomaszczyk, Jerzy. 1983. On bilingual dictionaries: The case for bilingual dictionaries for foreign language learners. In Lexicography: principles and practice, ed. Reinhard R. K. Hartman. London and New York: Academic Press, 41-51.

Tono, Yukio. 2001. Research on dictionary use in the context of foreign language learning: focus on reading comprehension. Tübingen: Niemeyer. 
Turunen, Natalia. 2006. Feststellungen von Lakunen im finnischen Russischunterricht. In LakunenTheorie. Ethnopsycholinguistische Aspekte der Sprach- und Kulturforschung, eds. Igor Panasiuk and Hartmut Schröder. Berlin: LIT Verlag, 260-266.

Vinay, Jean P., and Jean Darbelnet. 1958. Stylistique comparée du français et de l'anglais: méthode de traduction. Nouvelle édition revue et corrigée. Paris: Didier

Wipprecht, Claudia. 2005. The concept of 'field' and 'gap'. Norderstedt: GRIN Verlag.

Yamada, Shigeru. 2001. The abilities needed for EFL dictionary use and how to teach them. Studies in Lexicography 11. Seoul: Center for Linguistic Informatics Development, Yonsei University, $113-125$.

Yamada, Shigeru. 2010. EFL dictionary evolution: Innovations and drawbacks. In English learners' dictionaries at the DSNA 2009, eds. Ilan J. Kernerman and Paul Bogaards. Tel Aviv: K Dictionaries, 147-168.

Yamada, Shigeru. 2011. The Challenges of the Shift from Print to Electronic Dictionaries, In ASIALEX2011 proceedings. Lexicography: theoretical and practical perspectives. Papers submitted to the seventh ASIALEX biennial international conference Kyoto Terrsa, Kyoto, Japan, August 22-24, 2011, eds. Kaoru Akasu and Satoru Uchida. The Asian Association for Lexicography, 566-575.

Yamada, Shigeru. 2014. Guide to the practical usage of English monolingual learner's dictionaries: Effective ways of teaching dictionary use in the English class. Tokyo: Oxford University Press. http://www.oupjapan.co.jp/teachers/resources/oup_guide_to_dictionary_use_2014_E.pdf. Accessed 10 February 2015.

Zgusta, Ladislav. 1984. Translational equivalence in the bilingual dictionary. In LEXeter'83 proceedings: papers from the international conference on lexicography at Exter, 9-12 September 1983, ed. Reinhard R. K. Hartmann. (Lexicographica Series Maior 1). Tübingen: M. Niemeyer, 147-154. 